\title{
Atrial fibrillation and psychological factors: A systematic review
}

\author{
Federica Galli ${ }^{\text {Corresp., }}{ }^{1}$, Lidia Borghi ${ }^{1}$, Stefano Carugo ${ }^{1,2}$, Marco Cavicchioli ${ }^{3}$, Elena Maria Faioni ${ }^{1,4}$, Maria \\ Silvia Negroni ${ }^{2}$, Elena Vegni ${ }^{1}$ \\ 1 Department of Health Sciences, University of Milan, Milan, Italy \\ 2 Cardiology Unit and UCIC, UOC Cardiology, ASST Santi Paolo e Carlo, Milan, Italy \\ 3 Vita-Salute San Raffaele University, Milano, MI, Italia \\ 4 SIMT, ASST Santi Paolo e Carlo, Milan, Italy \\ Corresponding Author: Federica Galli \\ Email address: federica.galli1@unimi.it
}

ABSTRACT. Background. Psychological factors have been suggested to have an influence in Atrial Fibrillation (AF) onset, progression, severity and outcomes, but their role is unclear and mainly focused on anxiety and depression.

Methods. A systematic electronic search had been conducted to identify studies exploring different psychological factors in AF. The search retrieved 832 articles that were reviewed according to inclusion criteria: observational study with a control/comparison group; use of standardized and validated instruments for psychological assessment. Results were summarized qualitatively and quantitatively by effect size measure (Cohen's $d$ and its 95\% confidence interval). Cochrane Collaboration guidelines and the PRISMA Statement were adopted. Results. Eight studies were included in the systematic review. Depression was the most studied construct/ but only one study showed a clear link with AF. The remaining studies showed small and non-significant $(95 \% \mathrm{Cl},-0.25-1.00)$ differences between $\mathrm{AF}$ and controls, no differences in frequency of depression history $(95 \% \mathrm{Cl},-0.14-0.22)$ or in case frequency $(95 \% \mathrm{Cl},-0.50-0.04)$. Miscellaneous results were found as far as anxiety: AF patients showed higher levels when compared to healthy subjects $(95 \% \mathrm{Cl}, 2.05-2.95)$, but findings were inconsistent when compared to other heart diseases. Considering personality and life-events preceding AF, we respectively found a large $(95 \% \mathrm{Cl}, 1.87-2.49)$ and a moderate to large effect $(95 \% \mathrm{Cl}, 0.48-0.98)$. Discussion. The small number of studies does not allow to draw clear-cut conclusions on the involvement of psychological factors in AF. Promising lines of research are related to personality and adverse life-events, and to the increase of longitudinal design studies. Some methodological problems could be overcome by including clinical psychologists in the implementation of research protocols. 
1

ATRIAL FIBRILLATION AND PSYCHOLOGICAL FACTORS:

1. Department of Health Sciences, University of Milan, Milan, Italy.

7 2. Cardiology Unit and UCIC, UOC Cardiology, ASST Santi Paolo e Carlo

8 3. Vita-Salute San Raffaele University, Milan, Italy.

9 4. SIMT, ASST Santi Paolo e Carlo, Milan, Italy.

5. Clinical Psychology, ASST Santi Paolo e Carlo, Milan, Italy.

14 Correspondence to:

15 Federica Galli

16 federica.galli1@unimi.it 
ABSTRACT. Background. Psychological factors have been suggested to have an influence in Atrial Fibrillation (AF) onset, progression, severity and outcomes, but their role is unclear and mainly focused on anxiety and depression.

Methods. A systematic electronic search had been conducted to identify studies exploring different psychological factors in AF. The search retrieved 832 articles that were reviewed according to inclusion criteria: observational study with a control/comparison group; use of standardized and validated instruments for psychological assessment. Results were summarized qualitatively and quantitatively by effect size measure (Cohen's $d$ and its 95\% confidence interval). Cochrane Collaboration guidelines and the PRISMA Statement were adopted. Results. Eight studies were included in the systematic review. Depression was the most studied construct/ but only one study showed a clear link with AF. The remaining studies showed small and nonsignificant (95\% CI, $-0.25-1.00)$ differences between $\mathrm{AF}$ and controls, no differences in frequency of depression history ( $95 \% \mathrm{CI},-0.14-0.22)$ or in case frequency $(95 \% \mathrm{CI},-0.50-0.04)$. Miscellaneous results were found as far as anxiety: AF patients showed higher levels when compared to healthy subjects ( $95 \%$ CI, 2.05-2.95), but findings were inconsistent when compared to other heart diseases. Considering personality and life-events preceding AF, we respectively found a large (95\% CI, 1.87-2.49) and a moderate to large effect (95\% CI, 0.48-0.98). Discussion. The small number of studies does not allow to draw clear-cut conclusions on the involvement of psychological factors in AF. Promising lines of research are related to personality and adverse lifeevents, and to the increase of longitudinal design studies. Some methodological problems could be overcome by including clinical psychologists in the implementation of research protocols. 


\section{INTRODUCTION}

Atrial fibrillation (AF) is the most common arrhythmia in clinical practice, with an overall prevalence of $1-2 \%$ in the general population [Lip, Tse \& Lane, 2012; Piccini et al., 2012] and an incidence that increases with age. In Europe, $3.7-4.2 \%$ in the age range of $60-70$ and $10-17 \%$ of those 80 years or older are affected by AF, and, in the next 50 years, its prevalence is expected to double, as a consequence of the prolongation of life expectancy [ZoniBerisso et al., 2014].

On the basis of the presentation, duration, and spontaneous termination of AF episodes, five types of AF are classified: first diagnosed, paroxysmal, persistent, long-standing persistent, and permanent AF [Kirchhof et al., 2016] . AF is associated with a higher relative risk of allcause mortality, stroke, cardiovascular mortality, cardiac events, and heart failure (more in women than in men) [Emdin et al., 2016] and a number of risk factors (see Appendix 1). However, to the best of our knowledge, the studies on risk factors did not explore the role of psychological factors. The lack of correspondence between symptoms and ECG findings [Lampert 2015], may be clarified evidencing if and which psychological factors are linked to AF . Two reviews analysed the link of AF with anxiety and depression [McCabe 2010; Patel et al., 2013] suggesting a condition of comorbidity. However, the comorbidity of anxiety and depression is common in so many and different disorders and diseases [American Psychiatric Association, 2013; Galli et al., 2016; Galli 2017] that we need to enlarge our perspective. Temperament, adverse childhood experience, stressful life events and personality are well known psychological mechanisms representing risk and prognostic factors for anxiety and mood disorders, [American Psychiatric Association, 2013]. In this perspective, the aim of the present study is to make a systematic review of the numerous studies dealing with psychological factors 
63 in AF, in order to identify factors not simply linked to AF, but also influencing its onset, severity

64 and clinical outcome. To the best of our knowledge, no systematic reviews have been realised on

65 the role of psychological factors in AF. The recognition of the involvement of such factors may

66 help the identification of new clinical strategies for the management of AF.

\section{METHODS}

69

\section{Search strategy}

To include the broadest range of relevant literature, electronic searches were conducted on the major databases in the field of health and social sciences: Pubmed, Scopus, Embase, PsycInfo, and Web of Science. The search was performed using Mesh terms/Keywords (depending on the database) with the same search strategy: "Atrial fibrillation" AND "Psychological distress" OR “Anxiety” OR “Depression” OR "Emotional distress” OR "Personality" OR “Psychiatric disorder" OR “Temperament” OR "Life-event". The selection of the search terms are based on the clinical experience and the topic literature on psychological factors involved in physical disorders [American Psychiatric Association, 2013]. The search was limited to English-written publications, and to the period from 2000 to the present, to focus on contemporary psychological models, theories, and assessment tools. An additional analysis of the reference list in each selected paper was also performed. When the full text was not retrievable, the study was excluded.

The electronic bibliographic search was conducted in December 2016.

\section{Selection Criteria and Data Extraction}

Inclusion criteria: 
86 - Studies with an analytical study design as defined by Grimes and Schulz [Grimes \& Schulz,

87 2002] (i.e., an observational study with a comparison or control group);

88 - Studies involving patients with a diagnosis of AF [Fuster et al., 2011];

89

- Studies adopting standardised and validated instruments to assess psychological factors;

- Studies written in English language.

91 Exclusion criteria:

92 - Case reports, reviews, Letters to the Editor, meeting abstracts, book chapters;

93 - Pharmacological and behavioural intervention trials, surgical protocols, or validation of

94 measurement instruments;

95 - Studies with intra-group controls (e.g., men $v s$ women; stratification according to AF severity 96 or AF type);

97 - Studies addressing only quality of life.

\section{Data extraction}

Study selection was performed by two independent reviewers with research expertise in 101 clinical psychology (FG and LB) who assessed the relevance of the study for the objectives of 102 this review. This first round of selection was based on the title, abstract, and keywords of each 103 study. If the reviewers did not reach a consensus or the abstract did not contain sufficient 104 information, the full text was reviewed.

105 In the second phase, full-text reports have been evaluated to detect whether the studies met the 106 inclusion criteria (Figure 1).

107 A standardised data extraction form was prepared; data was independently extracted by two of 108 the authors (FG and LB) and inserted in a study database. A process of discussion/consensus 
109 110 reviewers.
112

113

114

115

116

117

118

119

120

121

122

123

124

125

126

127

128

129

130

131

moderated by a third reviewer (EV) [Furlan et al., 2009] resolved discrepancies between

\section{Statistical methods}

A systematic analysis was conducted according to the Cochrane Collaboration guidelines [Higgins \& Green, 2011] and the PRISMA Statement [Moher et al., 2009]. As the included studies were highly heterogeneous in terms of participants, variables, instruments, and outcomes, it was not considered appropriate to undertake a meta-analysis [Higgins \& Green, 2011]; however, effect size computations were performed using Cohen's $d$ [Cohen, 1988] and its 95\% confidence interval [Borestein et al., 2011] for each outcome measure within each study. The index was primarily calculated using descriptive statistics reported in the results section of each study. When binary data was reported, we estimated the Odds Ratio and then we applied the appropriate procedures [Borestein et al., 2011] to convert it to $d$. Cohen's $d$ values less than or equal to $0.20,0.50$ and 0.80 were interpreted as small, medium and large effect size respectively [Cohen, 1988]. Furthermore, in order to assess possible confounding factors, such as sample size and year of publication, that might influence effect size values, we estimated correlations using Spearman's rank correlation based on bootstrap methodology (bias corrected and accelerated) [Davidson \& Hinkley, 1997]. 1000 bootstrap independent samples were used with a $p$ (2-tailed) $<0.05$.

\section{Risk of bias}

In order to assess the risk of bias of the included studies, we adopted a tool for assessing risk-of-bias in nonrandomized studies developed by Kim and colleagues [Kim et al., 2013]. In 
132 brief, two reviewers (MC and FG) independently extracted relevant information and data from

133 all eligible reports, and they independently applied criteria for judging the risk of bias for each

134 domain. Particularly, the Risk of Bias Assessment Tool for Nonrandomized Studies (RoBANS)

135 evaluates six domains with three different levels of risk of bias (i.e. high, low, unclear): a)

136 selection of participants; b) confounding variables; c) measurement of exposure; d) blinding of

137 outcome assessments; e) incomplete outcome data; f) selective outcome reporting.

138

139 RESULTS

We found eight studies that adopted a control group (Figure 1), for a total of 985641

subjects (89383 AF patients; 896109 healthy controls; 149 other heart diseases). The

psychological variables detected by the selected studies are described in Table 1. Table 2 summarizes the main characteristics and outcomes of the included studies.

Five studies [Thrall et al., 2007; Dabrowski et al., 2010; Perret-Guillaume et al., 2010; instruments. Nevertheless, we observed a high heterogeneity in the construct assessed and in the questionnaires adopted in each study. Three studies assessed anxiety, both in term of level of state (current) and trait (lifetime) [Thrall et al., 2007; Perret-Guillaume et al., 2010; Lioni et al., 2014].

Two studies investigated the role of life events on AF onset: one study highlighted the role of bereavement [Graff et al., 2016] and another the influence of Life Changes Unit [Mattioli et al., 2005].

One study evaluated the role of personality traits [Mattioli et al., 2005]; while two studies 154 [Perret-Guillaume et al., 2010; Whang et al., 2012] explored general mental health [Perret- 
155 Guillaume et al., 2010] and global psychological distress [Whang et al., 2012] with contrasting 156 findings.

157 Considering depression, only the study of Perret-Guillaume et al. [2010] found a large 158 significant (95\% CI: 2.63-3.57) difference in level of depression between AF patients and 159 healthy controls. The remaining studies showed a small and non-significant (95\% CI: $-0.14-0.52)$ 160 difference between individuals affected by AF and healthy controls. Considering the comparison 161 between AF patients and subjects with other heart diseases, we found small and null effect sizes

162 for both studies included in the current work [Thrall et al., 2007; Lioni et al., 2014] (respectively: 163 $d=0.35[0.02-0.77] ; d=0.26[-0.01-0.56])$. subjects exhibited more severe anxiety symptoms than healthy subjects [Schnabel et al., 2013] (95\% CI: 2.05-2.95). Inconsistent findings, instead, were present when anxiety (STAI state) was compared between AF and other heart diseases. Specifically, Thrall and colleagues [2007] found no significant differences in STAI state scores between AF and hypertensive patients.

Conversely, Lioni and colleagues [Lioni et al., 2014] showed that AF patients were characterized

170 by a more intense anxiety state than controls $(d=0.77[0.38-1.16])$. On the other hand,

171 consistent results were found when levels of anxiety trait were evaluated comparing AF to other

172 heart diseases: AF showed higher levels of anxiety trait than Supraventricular Tachycardias 173 subjects [Lioni et al., 2014] and hypertensive patients [Thrall et al., 2007]. In detail, this 174 difference was small to moderate and significant in both studies [Thrall et al., 2007; Lioni et al., 175 2014] (respectively: $d=0.41[0.02-0.80] ; d=0.34[0.07-0.61]$ ).

176 Considering the role of personality, a significant large (95\% CI: 1.87-2.49) difference was 177 found. Regarding the role of life events, the two studies [Mattioli et al., 2005; Graff et al., 2016] 
178 reported inconsistent results: the study on the Life Changes Units preceding AF [Mattioli et al.,

1792005 ] reported a moderate to large (95\% CI: 0.48-0.98) difference, while the study on partner

180 bereavement reported a small and insignificant effect $(d=0.19[-0.14-0.52])$.

One study evaluated general mental health using the DUKE test [Schnabel et al., 2013],

182 showing a moderate and significant (95\% CI: 0.20-0.90) effect size; conversely, the mental

183 health score evaluated by the SF-36 did not differ significantly $(\mathrm{p}=0.61)$. The longitudinal

184 investigation [Whang et al., 2012] on the role of the global psychological distress did not

185 evidence any significant difference for AF patients $(d=-.22[-.44-.00])$.

We then checked the effect of possible confounding factors such as sample size and year

of publication, we did not find any significant relations with effect size values. Consequently, we

might exclude that these aspects affected the extent of difference between AF patients and controls. The risk of bias is described in Table 2 .

190

191

192

193

\section{DISCUSSION}

The role of psychological factors has been extensively studied in AF, but any clear-cut conclusion is far to be reached on the basis of our systematic review. Principally, we have to stress the paucity of studies that we could select.

Our review shows that depression and anxiety remain the most studied psychological features in AF. Findings from longitudinal studies do not allow any conclusion on the direction of the association. Findings on depression [Thrall et al., 2007; Dabrowski et al., 2010; PerretGuillaume et al., 2010; Schnabel et al., 2013; Lioni et al., 2014] are difficult to compare and conclusions are far from consistent. Two unstructured reviews on anxiety and depression [McCabe, 2010; Patel et al., 2013], suggested a generic condition of comorbidity. In our review, 
200 only two studies supported a role for depression [Dabrowski et al., 2010; Perret-Guillaume et al.,

201 2010]. However, in one study [Perret-Guillaume et al., 2010] the assessment tool (Duke Health

202 Profile) was aimed at detecting the symptoms of depression (and anxiety) in the week before the

203 interview, so that any conclusion pertains only to that time span. Dabrowski et al., [2010] found

204 a higher prevalence of depression level in AF patients (especially in women) than controls, but

205 the effect size does not allow to support any rigorous conclusion.

206 Three studies assessed anxiety [Thrall et al., 2007; Perret-Guillaume et al., 2010; Lioni et

207 al., 2014] and conclusions, similarly to depression, are difficult to draw. We have the same

208 comments and conclusion reported on depression for the study of Perret-Guillaume et al.[2010] .

209 In the two other studies [Thrall et al., 2007; Lioni et al., 2014] trait anxiety slightly differed in

210 AF patients compared to controls, but such a difference inexplicably disappeared after 6-months

211 [Thrall et al., 2007]. In fact, trait anxiety refers to a stable lifelong component of the personality,

212 that is unlikely to change spontaneously in the brief period.

213 In synthesis, we can state that the role of anxiety and depression in AF is still largely

214 unknown. Unfortunately, the most studies we reviewed are observational, which are limited in

215 their capacity to infer causality. The little we know on depression probably goes in the direction

216 of being a consequence of permanent AF, and not a triggering factor. The overdrive of the

217 sympathetic nervous system is involved in AF [Shen, Zipes 2014; Uradu et al., 2017], and this is

218 the mechanism that might be linked to the role of anxiety in influencing AF. Longitudinal studies

219 are further warranted on this topic, because at the current state of the art we do not know if

220 depressed/anxious patients are more likely to develop AF, or if having AF makes it more likely

221 to develop depression/ anxiety. Furthermore, we do not know if a highly symptomatic patients

222 might be more likely to experience anxiety and depression than one who is asymptomatic. It is 
223 subsumed that lightening these points may have positive repercussions on the clinical

224 management of these kind of patients.

225

226

227

228

229

230

231

232

233

234

235

236

237

238

239

240

241

242

243

244

245

In the implementation of research protocol, we suggest to differentiate between patients with first diagnosed, paroxysmal, persistent or long-standing persistent, AF (some studies we analysed did not report any specificity on the diagnosis of AF), because the psychological milieu may differ accordingly. For a patient is very different to manage a new clinical condition or a long-standing persistent illness. In a similar way, the influences of psychological factors may reverberate differently in a chronic or acute condition, and vice-versa [Borghi, Galli, Vegni 2016]. The age of patients is another important variable, because we know that older the patient higher the risk of incidence of AF [Dewland et al., 2013], and age needs to be taken into consideration in the implementation of psychological research as well. For the psychological assessment, we suggest the choice of tools based on a life-time period to validate an elderly population (e.g. Geriatric Depression Scale) [Yesavage et al., 1982-1983]. Furthermore, psychological tests should be administrated in the appropriate context, as psychological assessment may be invalidated by invasive manoeuvres, such as catheter ablation [Lioni et al., 2014] or hospitalization [Perret-Guillaume et al., 2010. The sole study dealing with personality [Mattioli et al., 2005] shows interesting and significant findings for Type-A scale of Minnesota Multiphasic Personality Inventory (MMPI-2), that described AF patients as hard-driving, fastmoving and work-oriented individuals who frequently became impatient, irritable and annoyed. In general, we point out the paucity of studies (also considering not eligible ones) investigating the personality characteristics of AF patients. We think that other promising fields of research could be the study of specific personality traits. Literature shows that personality traits are highly 
246 associated with cardiovascular events [Kubzansky et al., 2006; Chida \& Steptoe, 2009], and it

247 can be hypothesized that they also play a role in the development of AF. Allostatic overload is

248 another topic that could be of interest. It describes the cost, in terms of biological burden, of the

249 organism continual adjustment to different challenges [Fava et al., 2010]. The role of allostatic

250 overload in AF has already been described [Offidani et al., 2013], but further studies are

251 required.

252 The role of adverse life-events is another interesting topic to enhance our knowledge of

253 AF . We included two studies [Mattioli et al., 2005; Graff et al., 2016] that brought evidence of a

254 role of life-events in predicting the onset of AF, giving even a time span of the increased risk (30

255 days before the onset of AF). Graff and colleagues [Graff et al., 2016] characterized life-events,

256 as related to the death of a partner, even if the effect size was small and non-significant.

257 Furthermore, we need to mention the shortcoming of catching data by an administrative

258 database. A population study [Karatzias, Yan \& Jowett, 2015] showed a significant relationship

259 between the death of a partner and heart disease, but a specific association with AF needs further

260 research. In detail, results reported in these studies might reflect biased effects, particularly

261 related to assessment procedures.

262 Consequently, future research should implement study designs with valid and reliable structured

263 clinical interviews in order to adequately evaluate specific psychological conditions.

264 Our study is not devoid of limitations. We could not perform a meta-analysis. Several

265 studies adopt the Hospital Anxiety and Depression Scale (HADS) [Zigmond \& Snaith, 1983],

266 but we could not select any of these studies for the inclusion in our systematic review, primarily

267 for the absence of a control/comparison group. The HADS is a screening test for detecting

268 symptoms of anxiety and depression in the week before hospitalisation and a valid tool in the 
269 older population as well [Flint \& Rifat, 2002]. HADS has been largely adopted to study AF

270 patients [Gehi et al., 2012; Akintade et al., 2015] and conclusions should always take into

271 consideration that the instrument does not allow to formulate a diagnosis of "anxiety" and/or

272 "depression", and only indicates the presence of referred symptoms.

273 In synthesis, our review does not allow any straightforward conclusion regarding the role

274 of psychological factors in AF. First, the study of depression seems to indicate it could be a

275 reaction to the diagnosis of AF. To confirm this, we need further studies that include a wider

276 time span, with psychological tests detecting both the current and lifetime situation. The only

277 longitudinal study [Wang et al., 2012] did not evidence any relationship, so that we are not

278 allowed to take any conclusion on the likely role of psychological distress as influencing AF.

279 Secondly, the study of personality characteristics is at its beginning in AF, but the knowledge of

280 personality features that may predispose to AF may be useful in a prevention perspective. In

281 general, we stress the need of studies adopting tests suitable for older patients. Finally, the role of

282 life events deserves further attention because evidence in this direction exists, but needs further

283 studies to clarify the specificity of the association.

284 Finally, we warmly suggest the involvement of clinical psychologists in planning and

285

realizing research in the medical field because the number of suitable instruments to detect the

286

psychological characteristics of patients is very wide, changes with age, and depends on the

287

psychological constructs one chooses to analyse. 


\section{References}

1. Akintade BF, Chapa D, Friedmann E, Thomas SA. The influence of depression and anxiety on health-related quality of life in patients with atrial fibrillation and atrial flutter. Journal of Cardiovascular Nursing 2015; 30(1):66-73. DOI: 10.1097/JCN.0000000000000107

2. American Psychiatric Association. DSM 5. American Psychiatric Association; 2013.

3. Benjamin EJ, Levy D, Vaziri SM, D'Agostino RB, Belanger AJ, Wolf PA. Independent risk factors for atrial fibrillation in a population-based cohort: The Framingham Heart Study. JAMA 1994; 271(11):840-844. DOI:10.1001/jama.1994.03510350050036

4. Borghi L, Galli F, Vegni E. The Patient-Centered Medicine as the Theoretical Framework for Patient Engagement. In book: Promoting Patient Engagement and Participation for Effective Healthcare Reform. 2016 Apr 1. Edited by IGI Global. pp 25-39. DOI: 10.4018/978-1-4666-99922.ch002

5. Borestein M, Hedges LV, Higgins JPT, Rothstein HR. Introduction to meta-analysis, first ed. Chichester, John Wiley \& Sons, 2011. DOI: 10.1002/jrsm.34

6. Chida Y, Steptoe A. The association of anger and hostility with future coronary heart disease: a meta-analytic review of prospective evidence. Journal of the American College of Cardiology 2009; 53:936-946. DOI: http://dx.doi.org/10.1016/j.jacc.2008.11.044

7. Cohen J. Statistical power analysis for the behavioral sciences, 2nd ed. Hillsdale: Lawrence Earlbaum Associates; 1988.

8. Dąbrowski R, Smolis-Bąk E, Kowalik I, Kazimierska B, Wójcicka M, Szwed H. Quality of life and depression in patients with different patterns of atrial fibrillation. Kardiologia Polska 2010; 68(10):1133-1139.

9. Davidson AC, Hinkley DV. Bootstrap methods and their application. New York: Cambridge University Press; 1997.

10. Dewland TA, Olgin JE, Vittinghoff E, Marcus GM. Incident atrial fibrillation among Asians, Hispanics, blacks, and whites. Circulation 2013; 3;128(23):2470-7. doi:10.1161/CIRCULATIONAHA.113.002449.

11. Emdin CA, Wong CX, Hsiao AJ, Altman DG, Peters SA, Woodward M, Odutayo AA. Atrial fibrillation as risk factor for cardiovascular disease and death in women compared with men: systematic review and meta-analysis of cohort studies. BMJ 2016; 352:h7013. DOI: https://doi.org/10.1136/bmj.h7013 
12. Fava GA, Guidi J, Semprini F, Tomba E, Sonino N. Clinical assessment of allostatic overload and clinimetric criteria. Psychotheapy and Psychosomatics 2010; 79:280-284. DOI: $10.1159 / 000318294$

13. Flint AJ, Rifat SL. Factor structure of the Hospital Anxiety and Depression Scale in older patients with major depression. International Journal of Geriatric Psychiatry 2002; 17(2):117-123. DOI: 10.1002/gps.535

14. Furlan AD, Pennick V, Bombardier C, Van Tulder M, Editorial Board, Cochrane Back Review Group. 2009 Updated method guidelines for systematic reviews in the Cochrane Back Review Group. Spine (Phila Pa 1976) 2009; 34(18):1929-1941. DOI: 10.1097/BRS.0b013e3181b1c99f

15. Fuster V, Ryden LE, Cannom DS, Ryde'n LE, MD, Cannom DS, Crijns HJ, Curtis AB, Ellenbogen KA, Halperin JL, Kay GN, Le Huezey JY, Lowe JE, Olsson BS, MD, PhD, FESC; Eric N. Prystowsky, Tamargo JL, Wann LS, 2011 ACCF/AHA/HRS focused updates incorporated into the ACC/AHA/ESC 2006 guidelines for the management of patients with atrial fibrillation: a report of the American College of Cardiology Foundation/American Heart Association Task Force on Practice Guidelines developed in partnership with the European Society of Cardiology and in collaboration with the European Heart Rhythm Association and the Heart Rhythm Society. Journal of the American College of Cardiology 2011; 48:149-246. DOI: http://dx.doi.org/10.1016/j.jacc.2006.07.018

16. Galli F, Lodi G, Sardella A, Vegni E. The role of psychological factors in burning mouth syndrome: a systematic review and meta-analysis. Cephalalgia 2016; Epub ahead of print DOI:10.1177/0333102416646769.

17. Galli F. Headache and anxiety/mood disorders: are we flow into a cul-de-sac? The Journal of Headache and Pain 2017, 18:6. doi: 10.1186/s10194-016-0710-1.

18. Gehi AK, Sears S, Goli N, Walker TJ, Chung E, Schwartz J, Wood KA, Guise K,. Mounsey JP. Psychopathology and symptoms of atrial fibrillation. Journal of Cardiovascular Electrophysiology 2012; 23(5):473-478. DOI: 10.1111/j.15408167.2011.02264.X

19. Graff S, Fenger-Grøn M, Christensen B, Pedersen HS, Christensen J, Li J, Vestergaard M. Long-term risk of atrial fibrillation after death of a partner. Open Heart 2016; 3(1), e000367. DOI: http://dx.doi.org/10.1136/openhrt-2015-000367

20. Grimes DA, Schulz KF. An overview of clinical research: the lay of the land. Lancet 2002; 359(9300):57-61. DOI: http://dx.doi.org/10.1016/S0140-6736(02)07283-5

21. Gutierrez A, Chung MK. Genomics of Atrial Fibrillation. Current Cardiology Report 
402

403

404

405

406

407

408

409

410

411

412

413

414

415

416

417

418

22. Higgins JPT, Green S. Cochrane Handbook for Systematic Reviews of Interventions Version 5.1.0 [updated March 2011]. The Cochrane Collaboration 2011. Available from www.handbook.cochrane.org.

23. Iribarren C, Sidney S, Bild DE, Liu K, Markovitz JH, Roseman JM, Matthews K. Association of hostility with coronary artery calcification in young adults: the CARDIA study, Coronary Artery Risk Development in Young Adults. JAMA 2000; 283:2546-2551. DOI:10.1001/jama.283.19.2546

24. Kanagala R, Murali NS, Friedman PA, Ammash NM, Gersh BJ, Ballman KV, Shamsuzzaman AS, Somers VK. Obstructive sleep apnea and the recurrence of atrial fibrillation. Circulation 2003; 107(20):2589-2594. DOI: https://doi.org/10.1161/01.CIR.0000068337.25994.21

25. Karasoy D, Bo Jensen T, Hansen ML, Schmiegelow M, Lamberts M, Gislason GH, Hansen J, Torp-Pedersen C, Olesen JB. Obesity is a risk factor for atrial fibrillation among fertile young women: a nationwide cohort study. Europace 2013;15(6):781-786. DOI: https://doi.org/10.1093/europace/eus422

26. Karatzias T, Yan E, Jowett S. Adverse life events and health: A population study in Hong Kong. Journal of Psychosomatic Research 2015; 78(2):173-177. DOI: http://dx.doi.org/10.1016/j.jpsychores.2014.11.024

27. Kim SY, Park JE, Lee YJ, Seo HJ, Sheen SS, Hahn S, Jahng BH, Son HJ. Testing a tool for assessing the risk of bias for nonrandomized studies showed moderate reliability and promising validity. Journal of clinical epidemiology 2013; 66(4):408-414. DOI: http://dx.doi.org/10.1016/j.jclinepi.2012.09.016

28. Kirchhof P, Benussi S, Kotecha D, Ahlsson A, Atar D, Casadei B, Castella M, Diener $\underline{\mathrm{HC}}, \underline{\text { Heidbuchel H}}, \underline{\text { Hendriks J, Hindricks, G }}$, Manolis AS, Oldgren J, Popescu

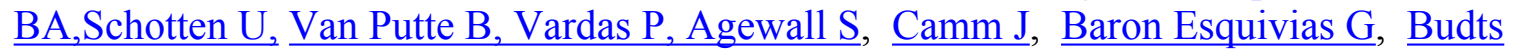
$\underline{\mathrm{W}}$, Carerj S, Casselman, F, Coca A, De Caterina R, Deftereos S, Dobrev D, Ferro JM, Filippatos, G, Fitzsimons D, Gorenek B, Guenoun M, Hohnloser SH, Kolh, P,Lip, $\underline{\text { GYH}}$, Manolis A, McMurray J, Ponikowski P, Rosenhek R, Ruschitzka F, Savelieva, I,

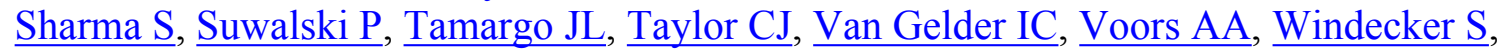
Zamorano JL, Zeppenfeld K. 2016 ESC Guidelines for the management of atrial fibrillation developed in collaboration with EACTS. European Heart Journal 2016; 37:2893-962. doi:10.1093/europace/euw295.

29. Kodama S, Saito K, Tanaka S, Horikawa C, Saito A, Heianza Y, Anasako Y, Nishigaki Y, Yachi Y, Iida KT, Ohashi Y, Yamada N, Sone H. Alcohol consumption and risk of atrial fibrillation: a meta-analysis. Journal of the American Colledge of Cardiology 2011; 57(4):427-436. DOI: http://dx.doi.org/10.1016/j.jacc.2010.08.641 
30. Krittayaphong R, Rangsin R, Thinkhamrop B, Hurst C, Rattanamongkolgul S, Sripaiboonkij N, Yindeengam A. Prevalence and associating factors of atrial fibrillation in patients with hypertension: a nation-wide study. BMC Cardiovascular Disorders 2016; 16(1):57. DOI: $10.1186 / \mathrm{s} 12872-016-0232-4$

31. Kubzansky LD, Cole SR, Kawachi I, Vokonas P, Sparrow D. Shared and unique contributions of anger, anxiety, and depression to coronary heart disease: a prospective study in the normative aging study. Annals of Behavioral Medicine 2006; 31:21-29. DOI: 10.1207/s15324796abm3101_5

32. Lampert R. ECG signatures of psychological stress. Journal of Electrocardiology 2015; 48:1000-1005. DOI: 10.1016/j.jelectrocard.2015.08.005

33. Lee H, Choi EK, Rhee TM, Lee SR, Lim WH, Kang SH, Han KD, Cha MJ, Oh S. Liver cirrhosis is a risk factor for atrial fibrillation: a nationwide, population-based study. Liver International 2017 Apr 22. doi: 10.1111/liv.13459.

34. Lioni L, Vlachos K, Letsas KP, Efremidis M, Karlis D, Asvestas D, Kareliotis V, Xydonas S, Dimopoulos N, Korantzopoulos P, Trikas A, Sideris A. Differences in quality of life, anxiety, depression in patients with paroxysmal atrial fibrillation and common forms of atrioventricular reentry supraventricular tachycardias. Indian Pacing and Electrophysiology Journal 2014;14(5):250-257. DOI: http://dx.doi.org/10.1016/S09726292(16)30796-3

35. Lip GY, Tse HF, Lane DA. Atrial fibrillation. Lancet 2012; 379(9816):648-661. doi: 10.1016/S0140-6736(11)61514-6.

36. Mattioli AV, Bonatti S, Zennaro M, Mattioli G. The relationship between personality, socio-economic factors, acute life stress and the development, spontaneous conversion and recurrences of acute lone atrial fibrillation. Europace 2005; 7(3):211-220. DOI: https://doi.org/10.1016/j.eupc.2004.02.006

37. McCabe PJ. Psychological distress in patients diagnosed with atrial fibrillation. Journal of Cardiovascular Nursing 2010; 25(1): 40-51. DOI: 10.1097/JCN.0b013e3181b7be36

38. Moher D, Liberati A, Tetzlaff J, Altman DG, PRISMA Group. Preferred reporting items for systematic reviews and meta-analyses: the PRISMA statement. Annals of Internal Medicine 2009;151(4):264-269. DOI: http://dx.doi.org/10.1371/journal.pmed.1000097

39. Mont L, Elosua R, Brugada J. Endurance sport practice as a risk factor for atrial fibrillation and atrial flutter. Europace 2009; 11(1):11-17. DOI: https://doi.org/10.1093/europace/eun289 
40. Mostofsky E, Penner EA, Mittleman MA. Outbursts of anger as a trigger of acute cardiovascular events: a systematic review and meta-analysis. European Heart Journal 2014; 35(21):1404-1410. DOI: https://doi.org/10.1093/eurheartj/ehu033

41. Myrstad M, Løchen ML, Graff-Iversen S, Gulsvik AK, Thelle DS, Stigum H, Ranhoff AH. Increased risk of atrial fibrillation among elderly Norwegian men with a history of long-term endurance sport practice. Scandinavian Journal of Medicine \& Science in Sports 2014;24(4):e238-244. DOI: 10.1111/sms.12150

42. Nawrot TS, Perez L, Kunzli N, Munters E, Nemery B. Public health importance of triggers of myocardial infarction: a comparative risk assessment. Lancet 2011; 377(9767): 732-740. DOI: http://dx.doi.org/10.1016/S0140-6736(10)62296-9

43. Offidani E, Rafanelli C, Gostoli S, Marchetti G, Roncuzzi R. Allostatic overload in patients with atrial fibrillation. International Journal of Cardiology 2013, 165(2):375-376. DOI: http://dx.doi.org/10.1016/j.ijcard.2012.08.026

44. Pallisgaard JL, Schjerning AM, Lindhardt TB, Procida K, Hansen ML, Torp-Pedersen C, Gislason GH. Risk of atrial fibrillation in diabetes mellitus: A nationwide cohort study. European Journal of Preventive Cardiology 2016; 23(6):621-627. DOI: https://doi.org/10.1177/2047487315599892

45. Patel D, McConkey ND, Sohaney R, McNeil A, Jedrzejczyk A, Armaganijan L. A systematic review of depression and anxiety in patients with atrial fibrillation: The mindheart link. Cardiovascular Psychiatry and Neurology 2013; 1-11. DOI: http://dx.doi.org/10.1155/2013/159850

46. Perret-Guillaume C, Briancon S, Wahl D, Empereur F. Quality of life in elderly inpatients with atrial fibrillation as compared with controlled subjects. The Journal of Nutrition Health \& Aging 2010; 14(2):161-166. DOI: 10.1007/s12603-009-0188-5

47. Piccini JP, Hammill BG, Sinner MF, Jensen PN, Hernandez AF, Heckbert SR, Benjamin EJ, Curtis LH. Incidence and prevalence of atrial fibrillation and associated mortality among Medicare beneficiaries, 1993-2007. Circulation: Cardiovascular Quality and Outcomes 2012; 5:85-93. DOI: https://doi.org/10.1161/CIRCOUTCOMES.111.962688

48. Shen MJ, Zipes DP. Role of the Autonomic Nervous System in Modulating Cardiac Arrhythmias. Circulation Research 2014; 114:1004-1021. DOI: 10.1161/CIRCRESAHA.113.302549

49. Schnabel RB, Michal M, Wilde S, Wiltink J, Wild PS, Sinning CR, Lubos E, Ojeda FM, Zeller T, Munzel T, Blankenberg S, E.Beutel M. Depression in atrial fibrillation in the general population. PLoS One 2013;8(12):e79109. DOI: http://dx.doi.org/10.1371/journal.pone.0079109

50. Tedrow UB, Conen D, Ridker PM, Cook NR, Koplan BA, Manson JE, Buring JE, Albert 
507

CM. The long- and short-term impact of elevated body mass index on the risk of new atrial fibrillation the WHS (women's health study). Journal of the American Colledge of Cardiology 2010; 55(21):2319-2327. DOI: 10.1016/j.jacc.2010.02.029

51. Thompson TS, Barksdale DJ, Sears SF, Mounsey JP, Pursell I, Gehi AK. The effect of anxiety and depression on symptoms attributed to atrial fibrillation. Pacing and Clinical Electrophysiology 2014; 37(4):439-446. DOI: 10.1111/pace.12292

52. Thrall G, Lip GY, Carroll D, Lane D. Depression, anxiety, and quality of life in patients with atrial fibrillation. Chest 2007; 132(4):1259-1264. DOI: 10.1378/chest.07-0036

53. Uradu A, Wan J, Doytchinova A, Wright KC, Lin AYT, Chen LS, Shen C, Lin SF, Everett TH, Chen PS. Skin sympathetic nerve activity precedes the onset and termination of paroxysmal atrial tachycardia and fibrillation. Heart Rhythm 2017;-:1-8. http://dx.doi.org/10.1016/j.hrthm.2017.03.030

54. Vlachos K, Letsas KP, Korantzpoulos P, Liu T, Georgopoulos S, Bakalakos A, Karamichalakis N, Xydonas S, Efremidis M, Sideris A. Prediction of atrial fibrillation development and progression: current perspectives. World Journal of Cardiology 2016; 8(3):267-276. DOI: 10.4330/wjc.v8.i3.267

55. Watanabe H, Watanabe T, Sasaki S, Nagai K, Roden DM, Aizaw Y. Close bidirectional relationship between chronic kidney disease and atrial fibrillation: the Niigata preventive medicine study. American Heart Journal 2009; 158(4):629-636. DOI: http://dx.doi.org/10.1016/j.ahj.2009.06.031

56. Wittstein IS, Thiemann DR, Lima JA, Baughman KL, Schulman SP, Gerstenblith G, Wu KC, Rade JJ, Bivalacqua TJ, Champion HC., Neurohumoral features of myocardial stunning due to sudden emotional stress. The New England Journal of Medicine 2005; 352(6):539-548. DOI: 10.1056/NEJMoa043046

57. Woeber KA. Thyrotoxicosis and the heart. The New England Journal of Medicine 1992; 327(2):94-98. DOI: 10.1056/NEJM199207093270206

58. Yesavage JA, Brink TL, Rose TL, Lum O, Huang V, Adey M, Leirer VO. Development and validation of a geriatric depression screening scale: a preliminary report. Journal of Psychiatric Research 1982-1983; 17(1):37-49. DOI: http://dx.doi.org/10.1016/00223956(82)90033-4

59. Zigmond AS, Snaith R. The hospital anxiety and depression scale. Acta Psychiatrica Scandinavica 1983; 67(6):361-370. DOI: 10.1111/j.1600-0447.1983.tb09716.x

60. Zhu W, Yuan P, Shen Y, Wan R, Hong K. Association of smoking with the risk of incident atrial fibrillation: A meta-analysis of prospective studies. International Journal of Cardiology 2016; 1;218:259-66. doi: 10.1016/j.ijcard.2016.05.013. 
551

552

553

554

555

556

557

558
61. Zoni-Berisso M, Lercari F, Carazza T, Domenicucci S. Epidemiology of atrial fibrillation: European perspective. Clinical Epidemiology 2014; 6:213-220. DOI: 10.2147/CLEP.S47385. 
Table 1. Overview of the selected studies

\begin{tabular}{|c|c|c|c|c|c|c|c|c|c|}
\hline $\begin{array}{c}\text { First } \\
\text { Author, } \\
\text { Year }\end{array}$ & $\begin{array}{c}\mathrm{N} \\
\text { Sample } \\
\text { (mean age, } \\
\text { SD) } \\
\end{array}$ & \begin{tabular}{|c|}
$\mathbf{N}$ \\
Controls \\
(mean age,, $\mathrm{SD})$
\end{tabular} & AF diagnosis* & AF PATTERN & Questionnaire (s) & \begin{tabular}{|l|} 
Study design \\
\end{tabular} & $\begin{array}{l}\text { Significant Findings } \\
\text { compared to } \\
\text { control(s)/(p) }\end{array}$ & $\begin{array}{l}\text { Effect size } \\
d(95 \% \mathrm{CI})\end{array}$ & Note \\
\hline $\begin{array}{l}\text { Mattioli et } \\
\text { al., } 2005\end{array}$ & $\begin{array}{l}116 \\
(54 \pm 7)\end{array}$ & $116(54 \pm 6.5)$ & $\begin{array}{l}\text { - "new and clearly } \\
\text { recognizable onset of } \\
\text { symptoms including } \\
\text { palpitations, dyspnea or } \\
\text { dizziness, or a combination } \\
\text { of these symptoms". } \\
\text { Confirmation by ECG. }\end{array}$ & $\begin{array}{l}\text { - First diagnosed } \\
\text { acute episode of } \\
\text { lone AF }\end{array}$ & $\begin{array}{l}\text { - Minnesota } \\
\text { Multiphasic } \\
\text { Personality Inventory } \\
\text { (MMPI-2)-Type A } \\
\text { scale. } \\
\text { - Life Changes } \\
\text { Scaling. }\end{array}$ & Cross-sectional & \begin{tabular}{|l|} 
- pattern of Type A \\
behavior in $20 \%$ of AF \\
vs $9 \%$ of controls \\
$(p<.001)$ \\
-Life Changes Unit in \\
AF was $56 \pm 33$ vs $34 \pm 27$ \\
in controls $(p<.01)$.
\end{tabular} & $\begin{array}{c}d \text { pattern Type } \\
\text { behavior } \\
2.18 \\
(1.87-2.49) \\
\\
\text { d life change } \\
\text { units } 0.73 \\
(0.48-0.98)\end{array}$ & $\begin{array}{l}\text {-increasing level } \\
\text { of Life Changes } \\
\text { Units was } \\
\text { associated with } \\
\text { greater risk of } \\
\text { AF. } \\
\text {-Spontaneous } \\
\text { conversion of AF } \\
\text { has predicted by } \\
\text { acute stress and } \\
\text { type-A behavior. }\end{array}$ \\
\hline $\begin{array}{l}\text { Thrall et } \\
\text { al., } 2007\end{array}$ & $101(66.3 \pm 11)$ & $\begin{array}{l}97 \\
\text { (hypertensive) } \\
(68 \pm 7.2)\end{array}$ & - Current criteria & $\begin{array}{l}\text { - Recurrent AF } \\
(\mathrm{N}=59) \\
\text { - Permanent AF } \\
(\mathrm{N}=42)\end{array}$ & $\begin{array}{l}\text {-Beck Depression } \\
\text { Inventory (BDI) } \\
\text {-State-trait Anxiety } \\
\text { Inventory (STAI) }\end{array}$ & Cross-sectional & \begin{tabular}{|l|} 
- BDI score did not \\
differ from controls both \\
baseline ( $\mathrm{p}=.32)$ and 6- \\
month follow-up \\
$(\mathrm{p}=0.48)$ \\
- Trait anxiety differed \\
from controls at baseline \\
$(\mathrm{p}=.03)$, but not 6-month \\
follow-up $(\mathrm{p}=.25)$
\end{tabular} & $\begin{array}{c}\text { depression } \\
0.26 \\
(-0.01-0.53) \\
\text { d anxiety trait } \\
.34 \\
(0.07-0.61)\end{array}$ & $\begin{array}{l}\text { - no influence of } \\
\text { depression on AF } \\
\text { - Higher level of } \\
\text { trait anxiety in } \\
\text { AF (only } \\
\text { baseline), but } \\
\text { STAI anxiety is a } \\
\text { measure of a } \\
\text { stable } \\
\text { psychologically } \\
\text { trait, and changes } \\
\text { in the little period } \\
\text { is enigmatic. } \\
\text {-no data have } \\
\text { been reported for } \\
\text { state anxiety } \\
\end{array}$ \\
\hline $\begin{array}{l}\text { Dąbrowski } \\
\text { et al. } 2010\end{array}$ & $\begin{array}{l}150 \text { (men: } \\
67.8 \pm 10.5) \\
\text { (women: } 64.1 \\
\pm 9.5 \text { ) }\end{array}$ & \begin{tabular}{|l|}
70 (men:56.5 \\
13.3 ); \\
(women: 54.8 \\
\pm 12.5 )
\end{tabular} & $\begin{array}{l}\text {-By exclusion: AF due to } \\
\text { valvular heart disease, with } \\
\text { valve prosthesis, } \\
\text { cardiomyopathy, heart } \\
\text { failure or left ventricular } \\
\text { dysfunction (ejection } \\
\text { fraction }<55 \% \text { ) were } \\
\text { excluded. }\end{array}$ & $\begin{array}{l}\text { - Paroximal AF } \\
(\mathrm{N}=61) \\
-\mathrm{Persistent} \mathrm{AF} \\
(\mathrm{N}=46) \\
-\mathrm{Permanent} \mathrm{AF} \\
(\mathrm{N}=43)\end{array}$ & $\begin{array}{l}\text {-Beck Depression } \\
\text { Inventory (BDI) }\end{array}$ & Cross-sectional & $\begin{array}{l}\text { - BDI scores showed } \\
\text { more severe symptoms } \\
\text { indicating } \\
\text { depression in all subsets } \\
\text { of patients with AF } \\
\text { compared to controls } \\
(\mathrm{p}<.01) \\
- \text { Higher level of } \\
\text { depression in women } \\
(\mathrm{p}<.0005) \text { than men (only } \\
\text { in AF group) }\end{array}$ & $\begin{array}{c}d \text { overall } \\
\text { depression } \\
0.38 \\
(-0.25-1.00)\end{array}$ & $\begin{array}{l}\text {-All forms of AF } \\
\text { have substantial } \\
\text { impact on the risk } \\
\text { of depression } \\
\text { occurrence. }\end{array}$ \\
\hline
\end{tabular}




\begin{tabular}{|c|c|c|c|c|c|c|c|c|c|}
\hline $\begin{array}{l}\text { Perret- } \\
\text { Guillaume } \\
\text { et al., 2010 }\end{array}$ & $\begin{array}{c}41 \\
(72.3 \pm 3.9)\end{array}$ & $\begin{array}{c}123 \\
(72 \pm 4)\end{array}$ & $\begin{array}{l}\text {-Permanent AF in } 30 \text { cases, } \\
\text { paroxysmal AF in } 7 \text { and new } \\
\text { diagnosis in } 4 .\end{array}$ & - Not specified & \begin{tabular}{|l|} 
- Duke Health Profile \\
(Duke) \\
- SF-36
\end{tabular} & Cross-sectional & $\begin{array}{l}\text {-Anxiety }(\mathrm{p}=.03) \text { and } \\
\text { Depression }(\mathrm{p}=.003) \\
\text { statistically relevant in } \\
\text { AF compared to controls. } \\
\text { - DUKE: Mental score } \\
\text { more impaired in AF } \\
\text { than controls }(\mathrm{p}<.01) \\
\text { - SF-36: Mental Health } \\
\text { score does not differ } \\
\text { from controls }(\mathrm{p}=.61)\end{array}$ & $\begin{array}{c}\text { danxiety } \\
2.50 \\
(2.05-2.95) \\
\text { ddepression } \\
3.08 \\
(2.63-3.57) \\
\text { dmentalhealth } \\
0.55 \\
(0.20-.90)\end{array}$ & \begin{tabular}{|l|} 
- Mental, Anxiety \\
and Depression \\
dimensions \\
remained \\
impaired even \\
when adjusted for \\
potential clinical \\
confounding \\
factors (coronary \\
artery disease or \\
chronic \\
respiratory \\
failure). \\
- Mental Health \\
scores disagree \\
comparing the \\
two different \\
assessment tools.
\end{tabular} \\
\hline $\begin{array}{l}\text { Whang et } \\
\text { al., } 2012\end{array}$ & 771 & 730 & $\begin{array}{l}\text { "An endpoint committee of } \\
\text { physicians reviewed medical } \\
\text { records for reported events } \\
\text { according to predefined } \\
\text { criteria. An incident AF } \\
\text { event was confirmed if there } \\
\text { was electrocardiographic } \\
\text { evidence for AF..." }\end{array}$ & Not specified & $\begin{array}{l}\text { Mental Health } \\
\text { Inventory-5 }\end{array}$ & Longitudinal & $\begin{array}{l}\text { Comparison of AF with } \\
\text { no-AF group with the } \\
\text { least global distress score } \\
\text { (NS) }\end{array}$ & $\begin{array}{c}\text { d psychological } \\
\text { distress } \\
0.12 \\
(-0.28-0.04))\end{array}$ & $\begin{array}{l}\text { The } \\
\text { psychological } \\
\text { distress did and a } \\
\text { proxy measure of } \\
\text { depression did not } \\
\text { differ between the } \\
\text { groups. }\end{array}$ \\
\hline \begin{tabular}{|l|} 
Schnabel \\
et al., 2013
\end{tabular} & $\begin{array}{c}309 \\
(64.8 \pm 8.2)\end{array}$ & $\begin{array}{c}9.680 \\
(55.2 \pm 10.8)\end{array}$ & $\begin{array}{l}\text {-History of self-reported AF } \\
\text { and/or electrocardiographic } \\
\text { documentation }\end{array}$ & - Not specified & $\begin{array}{l}\text { - Patient Health } \\
\text { Questionnaire (PHQ- } \\
\text { 9) } \\
\text { - Computer-assisted } \\
\text { question on the } \\
\text { previous history of any } \\
\text { depressive disorder as } \\
\text { diagnosed by a } \\
\text { physician. }\end{array}$ & Cross-sectional & $\begin{array}{l}\text { - no cases of depression } \\
\text { (PHQ-9 } \geq 10) \text { : } 7.3 \% \text { of } \\
\text { controls } v s 5.8 \% \text { of AF } \\
-\quad \text { History of } \\
\text { depression: } 16.2 \% \text { of AF } \\
\text { vs } 15.4 \% \text { of controls } \\
-\quad \text { more pronounced } \\
\text { somatic symptom } \\
\text { dimension of depression } \\
\text { in multivariate logistic } \\
\text { regression }(\mathrm{p}<.0001)\end{array}$ & $\begin{array}{c}d \text { history of } \\
\text { depression } \\
0.04 \\
(-0.14-0.22) \\
\\
d \text { caseness of } \\
\text { depression } \\
-0.23 \\
(-0.50-0.04)\end{array}$ & $\begin{array}{l}\text { - Age range: } 35- \\
74 \text { years } \\
\text { - Unclear as } \\
\text { "mental health } \\
\text { status" has been } \\
\text { assessed } \\
\text { - the conclusion } \\
\text { of "higher burden } \\
\text { of depressive } \\
\text { symptoms" is not } \\
\text { supported by the } \\
\text { analysis of } \\
\text { reported data }\end{array}$ \\
\hline
\end{tabular}




\begin{tabular}{|c|c|c|c|c|c|c|c|c|c|}
\hline $\begin{array}{l}\text { Lioni et } \\
\text { al., } 2014\end{array}$ & $\begin{array}{l}54 \\
(56.64 \pm 12.50)\end{array}$ & \begin{tabular}{|l|}
52 \\
$(40.46+14.96(\mathrm{su}$ \\
praventricolarta \\
chycardias \\
$(\mathrm{SVTs}))$
\end{tabular} & $\begin{array}{l}\text { - "current guidelines" } \\
\text {-patients were referred for } \\
\text { catheter ablation } \\
\text { (symptomatic, drug- } \\
\text { refractory, paroxysmal AF } \\
\text { vs symptomatic SVTs) }\end{array}$ & - Paroxysmal AF & $\begin{array}{l}\text {-Beck Depression } \\
\text { Inventory (BDI) } \\
\text {-State-trait Anxiety } \\
\text { Inventory (STAI) }\end{array}$ & Cross-sectional & 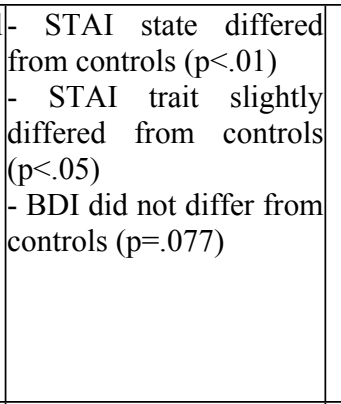 & $\begin{array}{c}d \text { anxiety trait } \\
0.41 \\
(0.02-0.80) \\
\\
d \text { anxiety state } \\
0.77 \\
(0.38-1.16) \\
\\
d \text { depression } \\
0.35 \\
(0.02-0.72)\end{array}$ & $\begin{array}{l}\text { - patients } \\
\text { "referred for } \\
\text { catheter ablation" } \\
\text { may not be } \\
\text { representative of } \\
\text { the AF population } \\
\text { (usually older as } \\
\text { well). }\end{array}$ \\
\hline $\begin{array}{l}\text { Graff et } \\
\text { al., } 2016\end{array}$ & 88.612 (NA) & 886.120 (NA) & $\begin{array}{l}\text {-first-time inpatient } \\
\text { diagnosis of AF by ICD-8 } \\
\text { and ICD-10 }\end{array}$ & $\begin{array}{l}\text { - First diagnosed } \\
\mathrm{AF}\end{array}$ & \begin{tabular}{|l|} 
- Danish Civil \\
Registration System \\
(for identifying \\
spousal/partner death).
\end{tabular} & Longitudinal & $\begin{array}{l}\text {-partner bereavement } \\
\text { was experienced by } 144 \\
\text { AF and } 1036 \text { controls. } \\
\text { - Transient higher risk } \\
(41 \%) \text { of developing AF } \\
\text { within } 30 \text { days after } \\
\text { death in the bereaved } \\
\text { population. }\end{array}$ & $\begin{array}{c}d \text { bareavement } \\
\text { and } A F \\
0.19 \\
(-0.14-0.52)\end{array}$ & $\begin{array}{l}\text { - The risk of AF } \\
\text { lasts about one } \\
\text { year and it is } \\
\text { especially high } \\
\text { for those who } \\
\text { were young and } \\
\text { those who lost a } \\
\text { relatively young } \\
\text { partner. }\end{array}$ \\
\hline
\end{tabular}

561 Legend: NA: Not Addressed

562 *AF diagnosis is reported referring to what declared by the Authors of each study 
Table 2. Risk of bias

\begin{tabular}{|c|c|c|c|c|c|c|}
\hline Studies & $\begin{array}{l}\text { Selection of } \\
\text { participants }\end{array}$ & $\begin{array}{l}\text { Confounding } \\
\text { variables }\end{array}$ & $\begin{array}{c}\text { Measurement of } \\
\text { exposure }\end{array}$ & $\begin{array}{l}\text { Blinding of } \\
\text { outcome } \\
\text { assessments }\end{array}$ & $\begin{array}{l}\text { Incomplete } \\
\text { outcome data }\end{array}$ & $\begin{array}{l}\text { Selective outcome } \\
\text { reporting }\end{array}$ \\
\hline Mattioli et al., 2005 & & & & & & \\
\hline Thrall et al., 2007 & & & & & & \\
\hline $\begin{array}{l}\text { Dąbrowski et al. } \\
2010\end{array}$ & & & & & & \\
\hline $\begin{array}{l}\text { Perret-Guillaumeet } \\
\text { al., } 2010\end{array}$ & & & & & & \\
\hline Whang et al., 2012 & & & & & & \\
\hline Schnabel et al., 2013 & & & & & & \\
\hline Lioni et al., 2014 & & & & & & \\
\hline Graff et al., 2016 & & & & & & \\
\hline
\end{tabular}

Figure legend

566

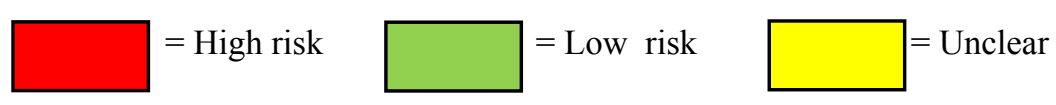




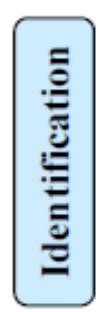

\begin{tabular}{|c|}
\hline $\begin{array}{c}\text { Records identified through } \\
\text { database research }\end{array}$ \\
$\mathrm{N}=1752$
\end{tabular}

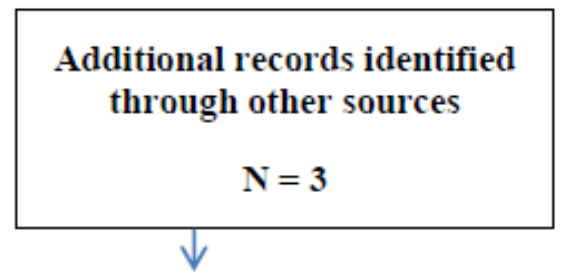

$\downarrow$
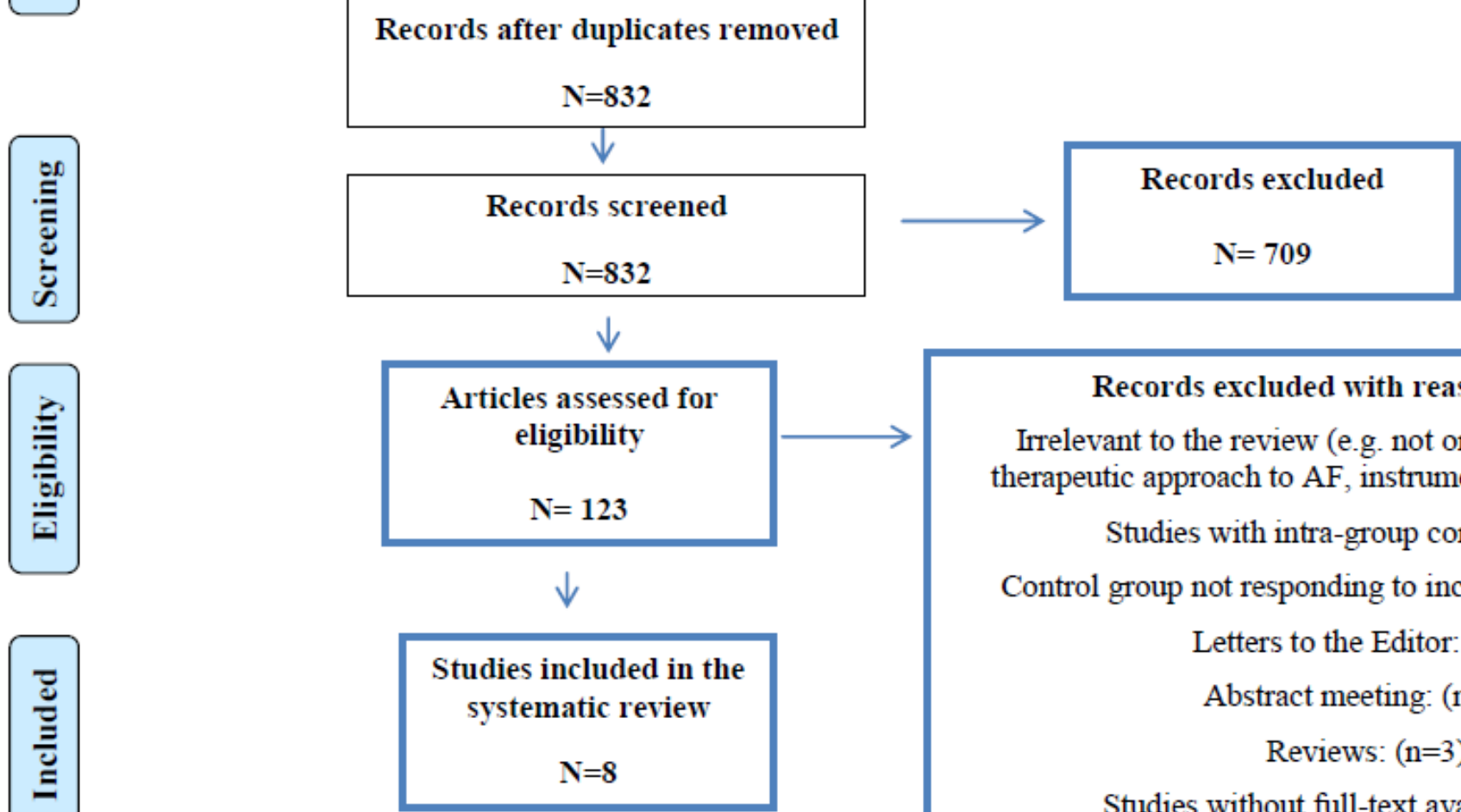

tudies included in the $\mathrm{N}=8$
Records excluded with reasons $(n=115)$ :

Irrelevant to the review (e.g. not on $\mathrm{AF}$, on surgical or therapeutic approach to $\mathrm{AF}$, instrument validation) $(\mathrm{n}=56)$

Studies with intra-group controls $(\mathrm{n}=28)$

Control group not responding to inclusion criteria: $(n=5)$

$$
\begin{aligned}
& \text { Letters to the Editor: }(n=4) \\
& \text { Abstract meeting: }(n=18)
\end{aligned}
$$$$
\text { Reviews: ( } \mathrm{n}=3 \text { ) }
$$

Studies without full-text available: $(\mathrm{n}=1)$ 
570 Appendix 1. Risk factors associated with the development and progression of atrial

\section{1 fibrillation}

\begin{tabular}{|l|l|}
\hline Risk factors & References \\
\hline Congestive heart failure & {$[$ Benjamin et al., 1994] } \\
\hline Hypertension & {$[$ Krittayaphong et al., 2016] } \\
\hline Diabetes mellitus & [Pallisgaard et al., 2016] \\
\hline Obesity & [Tedrow et al., 2010; Karasoy et al., 2013] \\
\hline Obstructive sleep apnoea syndrome & {$[$ Kanagala et al., 2003] } \\
\hline Chronic kidney disease & [Watanabe et al., 2009] \\
\hline Liver cirrhosis & {$[$ Lee et al., 2017] } \\
\hline Hyperthyroidism & [Woeber, 1992] \\
\hline Genetic factors & {$[$ Gutierrez \& Chung, 2016] } \\
\hline Age & {$[$ [Dewland et al., 2013] } \\
\hline Smoking & {$[$ Kodama et al., 2011] } \\
\hline Endurance exercise & \\
\hline
\end{tabular}

572 